Unimed

\title{
THE USE OF PRONOUN IN STRATEGY OF POLITENESS IN TALK SHOW PROGRAM
}

\author{
Andyka Yulia Adha \\ Sri Minda Murni \\ Anni Holila Pulungan \\ English Aplied Linguistic Program \\ Postgraduate Program-Universitas Negeri Medan
}

Diterima September 2020; Disetujui Oktober 2020; Dipublikasikan Desember 2020

\begin{abstract}
This qualitative descriptive research deals with The Use of Pronoun in Strategy of Politeness In Talk Show Program. This research observe the Use of Pronoun in Strategy of Politeness In Indonesia Lawyer Club ( ILC) Talk Show Program in some episode. The objectives of this study were to find out the types of politeness strategies are used in personal subject pronoun by the interviewees in Indonesia Lawyer Club ( ILC) Talk Show Program, and to investigate politeness strategies used the personal subject pronoun. The data were taken from the episode of Indonesia Lawyer Club Talk Show Program in 2018 years. The data were collected by downloading the video of Indonesia Lawyer Club Talk Show Program from youtube and then were transcribed. The data were analyzed by qualitative research based on interactive model which is created by Miles and Huberman. The result of the research shown the positive and negative politeness are used in Indonesia Lawyer Club ( ILC) by the same person. The same speaker and the same hearer used the politeness dynamically. It depends on topics/ issue whereas they understand or not in other hand they expert in the material. the researcher found that all types of Politeness Strategies proposed by Brown and Levinson (1987) found in the data. The data of Positive Politeness were consisted of 28 lines $(42.42 \%)$ which was the highest data from other strategies, while Off Record of Politeness Strategies was obtained as much 18 lines (30.30\%), then followed by Negative Politeness of Politeness Strategies was obtained as much 17 lines (22.73\%), and the last was Bald on Record with 3 lines (4.55\%).
\end{abstract}

Keywords: Politeness strategies, Pronouns, Talkshow Program

How to Cite: Yulia Adha, Andyka. (2020). The Use of Pronoun in Strategy of Politeness in Talk Show Program. Jurnal Linguistik Terapan-Pascasarjana Unimed. 17 (3): 205-211. 


\section{INTRODUCTION}

Politeness is a linguistics phenomenon involved in daily interaction that reveals how people use language to manage interpersonal relationships. The reason it is important to understand the nature and significance of politeness is because as soon as the interaction starts, each of the participant requires the mutual understandings of the norms of communicating to maintain relationship and interpret each other's behavior. The principle of politeness is to make all the parties relaxed and comfortable with one another in common social situation and is further Brown and Levinson ( 1987) broken down into four strategies of politeness, namely Bald on Record, Positive Politeness, Negative Politeness, and off Record Politeness strategies.

The aim of investigating this study is to find out the types of politeness strategies usage in pronoun speaker, and to find out of their reasons they way do.In communicating each other, the guest ( interviewees) in talk show often use the principle politeness by giving comfortable answer to what interviewer asks in talk show. In this case, the researcher will give the example so that it can be the preminary data of the researcher. This is one of utterance of Rocky Gerung in issues " Haruskah Ibukota Pindah? ( August, 20 2019). Then, in that talk show the guest used one of the type of politeness strategy in pronoun namely. Thus, the example can be seen as follow:

Rocky Gerung :Kalau kita ingin pindah kan sesuatu, berarti kita ingin sesuatu itu keluar dari dan masuk ke...Itu yang namanya pindah. Jadi ada arah dan vektor," "Sampai sekarang kita nggak tau alas an pindah dari Jakarta dan masuk ke Kalimantan. Bukan nggak ada alas an justru karena keterangannya bermacammacam,"

( If we want to move something, it means we want to get it out and get into.. That's mean moved. So it has purpose and vector". "Until now we don't know the reason why it is move from Jakarta to Kalimantan. It is not cause of there's no reason but the variety explanation.")

From Rocky Gerung statement we can see He uses Bald on Record, In this utterances he started to claim everybody with the strong and clear answer as we see "Kita". The pronoun in that utterances refer to Bald on Record to claim everybody have the same opinion with him.

Based on the background of this study, the problems of the study are formulated as in the following: 
1. What types of subject pronouns are used in strategy of politeness by the interviewees Talk Shows?

2. How are the subject pronouns used in strategy of politeness by the interviewees in Talk Show?

3. Why are the subject pronouns used in strategy of politeness strategies by the interviewees in the Talk Show?

In carrying out the research, it is necessary to state clearly the objectives of the study in the relation of the problem posed. The objectives are:

1. To investigate subject pronouns are used in strategy of politeness by the interviewees Talk Shows.

2. To describe about the subject pronouns are used in strategy of politeness by the interviewees in Talk Show.

3. To explain the subject pronouns are used in strategy of politeness strategies by the interviewees in the Talk Show.

This study attempts to find out the usage the types of politeness strategies in the issue " Perlukah Ibu Kota di Pindahkan? (20 August 2019) in Indonesia Lawyer Club (ILC) Talk Show in TV One which shown by the interviewees.

\section{METHODOLOGY}

In this research, qualitative descriptive method will be applied, which is basically interpretative research to purposefully select the video recorded that may be the best answer to the research problem. Bogdan and Biklen (1992:30) state that qualitative research is descriptive. Qualitative means to find out how a theory works in different phenomena whose data collected are in the form of words rather than numbers.

This analysis base on Brown and Levinson theory and this study try to investigate the usage, and their reasons in using the types of politeness strategies in pronoun.

The data of this study are conversational utterance in ILC talk show program. It will be taken from the video youtube of interviewees' utterances in a talk show then transcribed into written text. The sources are the video youtube of the talk show. The researcher chose one of the issues from the Talk Show program.

The data are collected by applying a documentary technique. In line with that, the writer had conducted some stages as stated in the following:

a. Downloading the talk shows episode on youtube.

b. Transcribing the interviewees' utterance in the talk show program into written text. 
c. Classifying the interviewees' utterances in which belong to the types of politeness strategies, namely Bald-on Record, Positive Politeness, Negative Politeness, and OffRecord politeness strategies.

d. Then, observing the daily conversations' utterance based on the theory to know their reasons why they applied the types of politeness strategies as the way they did.

In analyzing the data, inductive model is proposed by Miles, Huberman and Saldana (2014) will be applied. According to Miles, Huberman and Saldana (2014), there are three phases of data analysis. The phases are data condensation, data display, and conclusion drawing or verification.

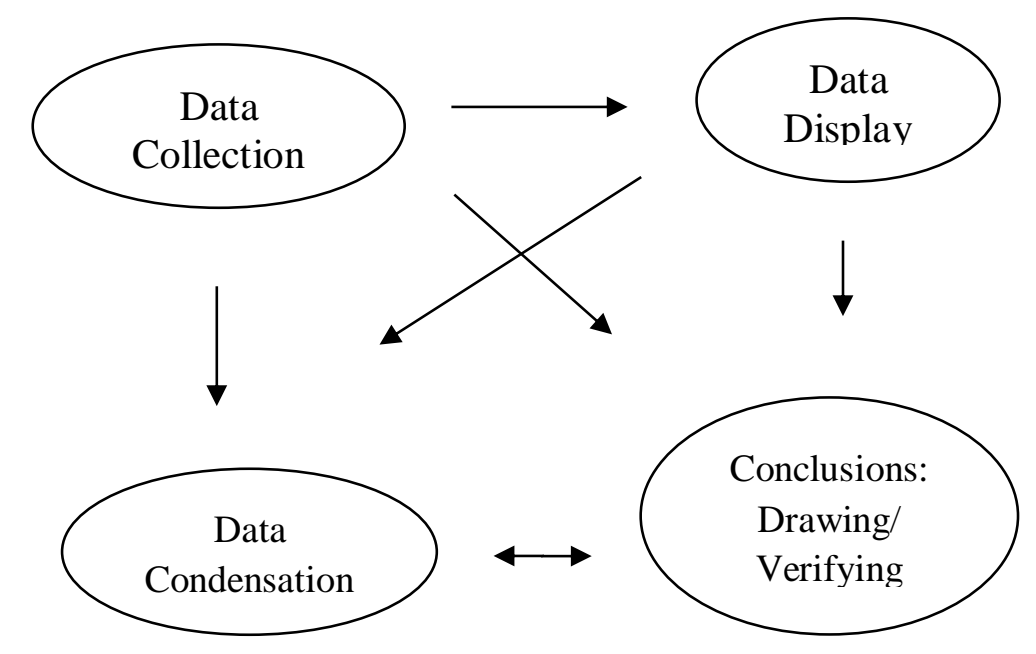

Figure 1 Interactive Model of Miles, Huberman, and Saldana (2014)

\section{FINDING AND DISCUSSION}

On the finding of politeness strategies in this research, it could be seen the results from Bald on Record, Positive Politeness, Negative Politeness, and Off Record that had been analyzed in the politeness strategies were exist in the data. However, not all types of strategies in Bald on Record, Positive Politeness, Negative Politeness, and Off Record were presented in the data. Then, Positive Politeness was the most common strategy found in the data with $42.42 \%$. This percentage was obtained by adding up all the data that contained of Politeness Strategies with Pronoun, then it was divided by the amount in each strategy. 


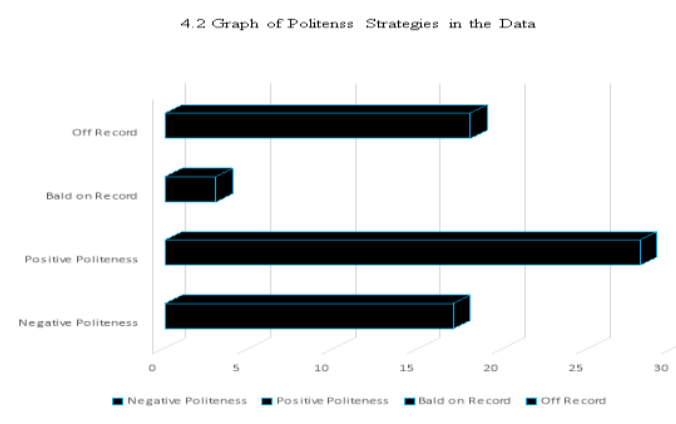

From the graph above, the researcher found that all types of Politeness Strategies proposed by Brown and Levinson (1987) found in the data. The data of Positive Politeness were consisted of 28 lines (42.42\%) which was the highest data from other strategies, while Off Record of Politeness Strategies was obtained as much 18 lines (30.30\%), then followed by Negative Politeness of Politeness Strategies was obtained as much 17 lines (22.73\%), and the last was Bald on Record with 3 lines (4.55\%).

From the research finding that have answered research questions, there were four strategies of Politeness analyzed in this research based on Brown and Levinson's theory, they were (Bald on Record, Positive Politeness, Negative Politeness, and Off Record). Each Politeness Strategies had their own sub-strategies, except Bald on Record.

Positive Politeness had fifteen strategies, they were notice, attend to hearer (his interests, wants, needs, goods), exaggerate (interest, approval, sympathy with hearer), intensify interest to hearer, use in group identity markers, seek agreement, avoid disagreement, presuppose/raise/assert common ground, joke, assert or presuppose speaker's knowledge of and concern for hearer's wants, offer, promise, be optimistic, include both speaker and hearer in the activity, give (or ask for) reasons, assume or assert reciprocity, and give gifts to hearer (goods, sympathy, understanding, cooperation). Then, Off Record also had fifteen strategies, they were give hints, give association clues, presuppose, understate, overstate, use tautologies, use contradictions, be ironic, use metaphors, use rhetorical questions, be ambiguous, be vague, over generalize, displace hearer, and be incomplete, use ellipsis. While, Negative Politeness had ten strategies, they were be inconventionally indirect, question, hedge, be pessimistic, minimize the imposition, give deference, apologize, impersonalize speaker and hearer: avoid the pronouns 'I' and 'you', state the FTA as a general rule, nominalize, and go on record as incurring a debt, or as not indebting hearer. The four strategies of Politeness had different functions according to their types by reaching 42.42\% Positive Politeness, 30.30\% for Off Record, 22.73 Negative Politeness, and 4.55\% for Bald on Record. 
In this research, the finding showed that Positive Politeness in analyzing data was very dominating in this research because it was used to threaten the positive face of their interlocutors because the speakers wanted the interlocutors to have the same opinions or thoughts to bring solidarity through the discussion. The researcher analyzed this thing happened because in a debate usually one party or side tried to get the other party or side to share a thought with it, so that what they were discussing could be won by that party.

\section{CONCLUSIONS}

After analyzing all the data based on the theory used, the study now can draw the following conclusions.

(1) All types of politeness strategies were used personal pronoun in Indonesia Lawyer Club Talkshow program, but the proportion of their occurances is not equal. Positive politeness strategies was the type of politeness strategy dominantly used by all interviewees, while bald record politeness strategies was the smallest count.

(2) Positive politeness strategy was used since the interviewees want to build the solidarity, familarity, and friendshio, and also to recognize H's positive face want and he also has the same want so that they can feel relax in conversation. While new finding out of Brown'a and Levinson's theory that the usage of positive politeness strategy since they want to make a joke or humor, and also the usgae off record strategy since the interviewee wants to avoid a deeo evaluation. It happened since this show broadcasted on television station

(3) The reason of using politeness strategies by the interviewees in identifying the listener was trigged by some reason. The reason of using bald on record during the interview was to convey their intention directly in order to avoid misunderstanding. The use of positive politeness strategies mostly was trigged by satisfying hearer positive face. The reason of using negative politeness was trigged by some reasons, namely to satisfy H's negative face, to pay respect and deference to listener and to maintain social distance and avoid the threat (or potential face lose) of advancing familarity towards the listener.

\section{REFERENCES}

Boghdan and Biklen. (1992). Qualitative Research for Education. USA: A Division of Simon and Schuster.

Brown, P and Levinson, S. (1987). Universal in Language Usage : Politeness Phenomena. Cambridge Univesity. 
Brown, P. and Levinson, S. (1987). Politeness: Some universals in language usage. Cambridge: Cambridge University Press.

Grundy, P. (1985). Doing Pragmatics. London : Edward Arnold.

Hobbs, P.(2003). The Medium is the Message: Politeness Strategies in Men's and Women's Voice Mail Messages. Journal of Pragmatics 35. (2003) 243 - 162.

Lakoff, R. (1990). Talking Power : The Politics of Language. New York: Harper and Row.

Leech, G. (1983). Principles of Pragmatics. London: Longman

Lincoln and Guba. (1985). Trustworthiness. Accessed on 22 nd June 2012.

Miles, Huberman and Saldana. (2014). Qualitative Data Analysis. California: Sage Publication, Inc.

Mills, S. (2003). Gender and Politeness. Cambridge; Cambridge University Press. 